\title{
Influences on Shanghai Free Trade Zone on China's Foreign Trade Enterprises and Countermeasures
}

\author{
Bing Guan \\ School of Economics, Harbin University of Commerce \\ Harbin, P. R. China \\ gbwyy@sina.com
}

\author{
Chunhui $\mathrm{Fu}$ \\ School of Economics, Harbin University of Commerce \\ Harbin, P. R. China \\ xiaohui.0088@163.com
}

\author{
Yiwei Li \\ School of Economics, Harbin University of Commerce \\ Harbin,P. R. China \\ Liyiwei8989@163.com
}

\begin{abstract}
Shanghai is the frontier of free trade in China. While the establishment of Shanghai Free Trade Zone will bring great opportunities to the development of foreign trade enterprises in China, make two-way investment more frequently between China and the world, it also brings challenges. China's foreign trade enterprises may take Shanghai Free Trade Zone as a platform and seize and take advantage of freedom of trade, freedom of circulation of fund and other incentives to solve their own problems, to strengthen corporate brand building, to accelerate the construction of modern enterprise system, and to promote China's foreign trade business development continuously.
\end{abstract}

Keywords-free trade zone; interest rate market; offshore financial centers; modern enterprise system

\section{I .THE ESTABLISHMENT OF SHANGHAi FrEE TRADE ZONE}

China (Shanghai) Pilot Free Trade Zone, was called for short Shanghai Free Trade Zone or Shanghai FTZ, which located in Shanghai. It is also the first free trade zone of china, and will bring decades of development bonus to Shanghai.

On August 2013, the State Council officially approved the establishment of China (Shanghai) Pilot Free Trade Zone. Shanghai FTZ regards Shanghai Waigaoqiao Free Trade Zone as the core area, supplementing Airport Free Trade Zone and Yangshan Harbor City, and becomes a new pilot ground for Chinese economy. Shanghai FTZ implements reform measures on government function transformation, financial systems, trade services, foreign investment, tax policy and so on, and vigorously promotes the development of Shanghai transit and offshore trade. The process of project approval has once encountered resistance. However, Premier Li Keqiang "Against All Odds " efforts finally made the project through. On September 29, 2013, Shanghai Free Trade Zone was formally established. Shanghai Free Trade Zone covers a total area of 28.78 square kilometers, including four customs supervisions: Shanghai Waigaoqiao Free Trade Zone, Waigaoqiao Bonded Logistics Park, Yangshan Free Trade Port Area and Pudong Airport Free Trade Zone.

\section{II . THE INFLUENCES OF ESTABLISHMENT OF SHANGHAI FTZ ON FOREIGN TRADE ENTERPRISES}

According to investment theory, investment location choices and interventions in the investment industry could adjust the industrial layout of enterprises, enhance the quality of enterprises, improve the industrial organization forms, not only to promote investment growth in Free Trade Zone, but also to enrich investment way of Shanghai foreign trade enterprises. Besides the implementation of more favorable financial policies and open tax policies not only can promote long-term stability cooperation with the foreign businessmen within area, prevent the exodus of foreign funds, but also conducive to foreign trade enterprises expand new export channels, to achieve export diversification, diversify market risk.

A.

Relaxing Enterprises Market Access

Shanghai Free Trade Zone policies tend to abolish restrictions of the investor qualifications in some sectors, relax market access for enterprises. Companies are able to apply for any area, and the way to start a business is more relaxed..

$B$.

\section{Business Freedom}

Business freedom includes business scope freedom, business place freedom and many other aspects of business premises. Compared with the Bonded Area, Free Trade Zone not only broke through the strict approval of business scope, but also broke limitation of geographical location, allowing enterprises to operate cross-area. Thus, not only can benefit the diversification of enterprises, but also can strengthen the economies of scale. Free Trade Zone provides convenience for operating enterprises as much as possible. This convenience is reflected in warehouses, factories, and other hardware facilities.

C. Customs Clearance

Free Employment, Convenient

In the Bonded Area, personnel access into the area needs to follow two limitations, so it is no doubt that this will greatly 
limit the effective free flow of human resources. Shanghai Free Trade Zone will implement the innovative new model of regulatory services, which includes "first-line completely liberalized gradually, safely and efficiently manage to secondline, free movement of regional goods", and this is the main difference between Shanghai Bonded Area. The so-called "first-line" refers to the border; "second-line" refers to the domestic market boundary, which is a space boundary of Free Trade Zone. Innovative regulatory model propose to frontline supervision focused on the person, port units make the necessary inspection and quarantine work only, in particular customs regulation will no longer use the batch mode, while use a centralized, classification, electronic monitoring mode to achieve people and goods flow fast and efficiently.!

D.

\section{Flexible Trade settlement}

Trade settlement is a very important aspect in international trade business for enterprises, It often closely links with investment and financing, which together constitute the corporate financial system. Foreign exchange management pilot of international trade settlement center established in Shanghai Waigaoqiao Free Trade Zone, which allows multinational companies to carry out the receipt and payment of funds, explores combination mode of re-payment of foreign exchange and settlement. XuQuan, deputy director of the Shanghai Financial Office, said that the content of Free Trade Pilot Zone covers the financial sector, including interest rate market, freedom of exchange rates, the opening up of the financial industry, product innovation and so on, and also involve some offshore business. In Shanghai Lujiazui Forum, YangXiong, Shanghai Mayor, also recently confirmed that Shanghai Free Trade Pilot Zone is applying for RMB capital account openness, and this reform will not change with the change of short-term liquidity, hot money flows. These changes tremendously impact to the business operations of foreign trade enterprises.

\section{E.}

\section{Minimal Corporate Taxes}

Shanghai will promote tax innovations, including offshore trade, low tax rate of finance, pay tax installments of foreign investment income and other preferential policies to support the development of enterprises in the Free Trade Zone. Preferential tax policy is all the more contentious topic. Because FTZ policy and innovation needs the value of replicate and promote, so the goal of building FTZ is not the traditional "Policy depression", which constitutes of preferential and special policies. The FTZ overall program, announced on September 27,2013 , did not mention the preferential of $15 \%$ corporate income tax which was prevalent in the media before, but "enterprises or individual shareholders, registered in the FTZ, whose revaluation of assets which arise from non-monetary assets foreign investment restructuring action, subject to pay income tax by installments, but can not exceed the period of five years." Personal income tax is suitable to equity incentive policy of personal income tax by installments which is implementing in Zhongguanchun and other regions of the pilot. Preferential tax policies of FTZ are lower than expected. But program represents that under the premise that in line with the direction of tax reform and international practice, it does not lead to the transfer of profits and the tax base does erosion.
Further study and perfect tax policy that adapt to foreign equity investment and Offshore Business Development are badly needed.

\section{DEVELOPMENT STRATEGIES OF FOREIGN TRADE ENTERPRISES IN CHINA}

A.

Accelerating the Establishment of

Modern Enterprise System and Improving Innovation

Capability

Only Chinese enterprises by developing themselves, enhancing international competitiveness can they better enjoy benefits from the FTZ. First of all, it is necessary for our enterprises to establish clear property rights, clear responsibilities, to separate management modern enterprise system as a corporate goal of self-improvement to enable enterprises to become sophisticated commodity producers and traders and market player. According to market signals, enterprises should adjust the direction and scale of production and operation timely, exert the fundamental function of market in the allocation of resources, accelerate the pace of corporate mergers and acquisitions, and enhance the scale of strength, reduce production costs. Secondly, in order to enhance Chinese enterprises' competitiveness in the international market, innovation is the key. And in terms of innovation in the international market, China's enterprises should be change export-oriented to create brand-oriented, creating brand, creating international market, in order to make Chinese enterprises by the enterprise's international operation rise to international operations business.

\section{$B$. Building and Enhancing Corporate Image}

In the fierce market competition, enterprises want to gain a competitive advantage. They must enhance the corporate image, accelerate brand building, and expand product awareness. Therefore, Chinese enterprises should make good use of the media, exhibitions and other medium, push corporate own culture and philosophy to the world market, vigorously publicize our products, improve product visibility, and vigorously promote the brand effect formation. Meanwhile, China's enterprises should develop the core competitiveness of products constantly, improve product quality, establish their own brand products and brand corporate.

\section{C.}

\section{Complete and Adequate Policies}

\section{Taking Great Advantages of}

Foreign trade enterprises should take the initiative to understand and master the various preferential policies of FTZ from the state, good docking in ideas, strategies and technically, reduce operating costs and the cost of exports, enhance their market competitiveness. Enterprises need to participate in policy advocacy regularly, learning the contents of preferential policies, and timely application and enjoy the relevant preferential policies. Such as FTZ propose more internationally competitive tax incentives, that is enterprises or individual shareholders, registered in the FTZ, whose revaluation of assets which arise from non-monetary assets foreign investment restructuring action, subject to pay income tax by installments, 
but can not exceed the period of five years. Understanding the product tariff concessions degree, both analysis of national product market, reposition export target country, according to changes in the demand market, adjustment of export product structure for timely, and also refer to the demand, improve the proportion of raw material inputs, improve the technological content of products, Raise the level of value-added products , expanding the list of tariff concessions export scale, optimize industrial structures, improve enterprises' efficiency. The establishment of Shanghai Free Trade Zone will make foreign trade enterprises within the region dock with the world more convenient, faster, it is contribute to foreign trade enterprises "going out" to develop, to participate in the international division the wider. Meanwhile, government propose that Shanghai Free Trade Zone should further promote investment facilitation mechanism for foreign enterprises, foreign trade enterprises should make full use of this platform, under the policy, actively innovate the business model, improve international trade and foreign investment efficiency and effectiveness, improve the ability of participation in international competition .

D.

Optimizing and Integrating Resource

Namely resources reserve and allocation, it is through a variety of methods of modern management, to regulate and allocate of resources reasonably, to run with high-quality, high efficiency, low cost, to ensure the high-profit business objectives. First of all, foreign companies need to reserve its internal resources fully, and then, according to the policies and market, re-configuration it, after that, they could grasp the opportunity to flow, gain high profits, good prospects and high efficiency.

\section{E. \\ Trade}

First of all, make best use of global resources effectively to obtain comparative advantage maximum, which is an effective means to circumvent and deal with trade barriers. Second is to facilitate payment of exchange. Generally, receipt and payment just only need to provide contracts and invoices, without having to provide declarations, entry-exit registration lists and other information, but must be sure this business is authenticity and legitimacy. The using of these favorable conditions will promote the development of offshore trade rapidly.

\section{$F$.}

Attaching Great Importance to

Foreign Trade Personnel and Business Management

Enterprises should strengthen internal organization and management innovation, strengthen cost management and financial management regarding funds as the core; develop and maintain high-quality personnel of understanding business and well operating foreign trade, through flexible employment mechanism, effective incentives and relaxed work environment to retain talent ; adopt a company's internal staff ( especially the backbone ) stock holdings as the core model, and establish foreign trade enterprises with efficient, vitality of the new forms of organization.

\section{REFERENCES}

[1] Lu Yang. Opportunities and challenges from Shanghai Free Trade Zone to foreign trade enterprises, 3rd,ed, Explore pilot, 2013, pp.51-52.

[2] Zhang Bei, Zhang Hua. The establishment of China - ASEAN Free Trade Area effects on Chinese enterprises and their countermeasures,4th,ed, Around Southeast Asia, 2004, pp.29-30.

[3] Li Bin. Studying on the development of Guangxi foreign trade enterprises - Based on China - ASEAN Free Trade Area framework ,4th,ed,Chinese collective economy, 2014, pp.40.

[4] Hou Wenping, Niu Guifang. Studying on the impact of establishment of China - ASEAN Free Trade Area to China's foreign trade,9th,ed, Foreign trade, 2012,pp. 9. 